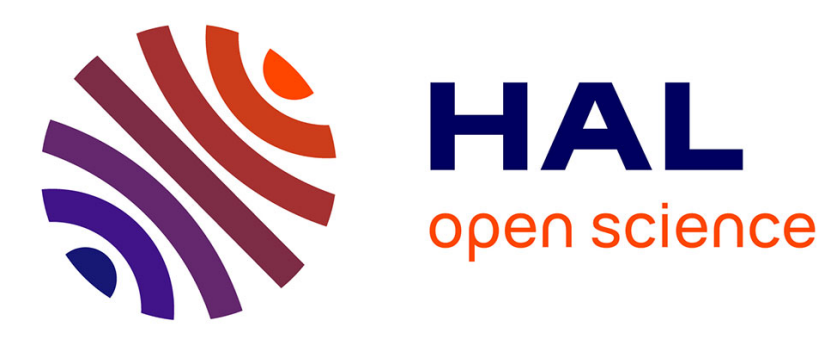

\title{
Photochemical Rearrangements in Heterocyclic Chemistry
}

\author{
Corentin Lefebvre, Lucas Fortier, Norbert Hoffmann
}

\section{To cite this version:}

Corentin Lefebvre, Lucas Fortier, Norbert Hoffmann. Photochemical Rearrangements in Heterocyclic Chemistry. European Journal of Organic Chemistry, 2019, 10.1002/ejoc.201901190 . hal-02318426

\section{HAL Id: hal-02318426 \\ https://hal.science/hal-02318426}

Submitted on 26 Nov 2020

HAL is a multi-disciplinary open access archive for the deposit and dissemination of scientific research documents, whether they are published or not. The documents may come from teaching and research institutions in France or abroad, or from public or private research centers.
L'archive ouverte pluridisciplinaire HAL, est destinée au dépôt et à la diffusion de documents scientifiques de niveau recherche, publiés ou non, émanant des établissements d'enseignement et de recherche français ou étrangers, des laboratoires publics ou privés. 


\title{
Photochemical Rearrangements in Heterocyclic Chemistry
}

\author{
Corentin Lefebvre, Lucas Fortier, Norbert Hoffmann* \\ CNRS, Université de Reims Champagne-Ardenne, ICMR, Equipe de Photochimie, UFR Sciences, \\ B.P. 1039, 51687 Reims, France, Tel: + 333269133 10, \\ e-mail: norbert.hoffmann@univ-reims.fr
}

\begin{abstract}
Heterocyclic compounds play an important role in many domains of chemistry. They are important structure elements in bioactive compounds. Photochemical reactions enable transformations of such compounds in a very convenient way. In many cases no chemical reagent is used. Members of one compound family can be transformed into members of another one. Three important types of photochemical rearrangements with heterocyclic compounds are discussed: Photochemical heteroatom isomerization involving heteroatoms and substituents, photochemical reactions involving hydrogen atom transfer (HAT) and photochemical electrocyclization.
\end{abstract}

\section{Key Words}

Heterocycles, Rearrangements, Photochemistry, Hydrogen Atom Transfer, Isomerization

\section{Graphical Abstract}

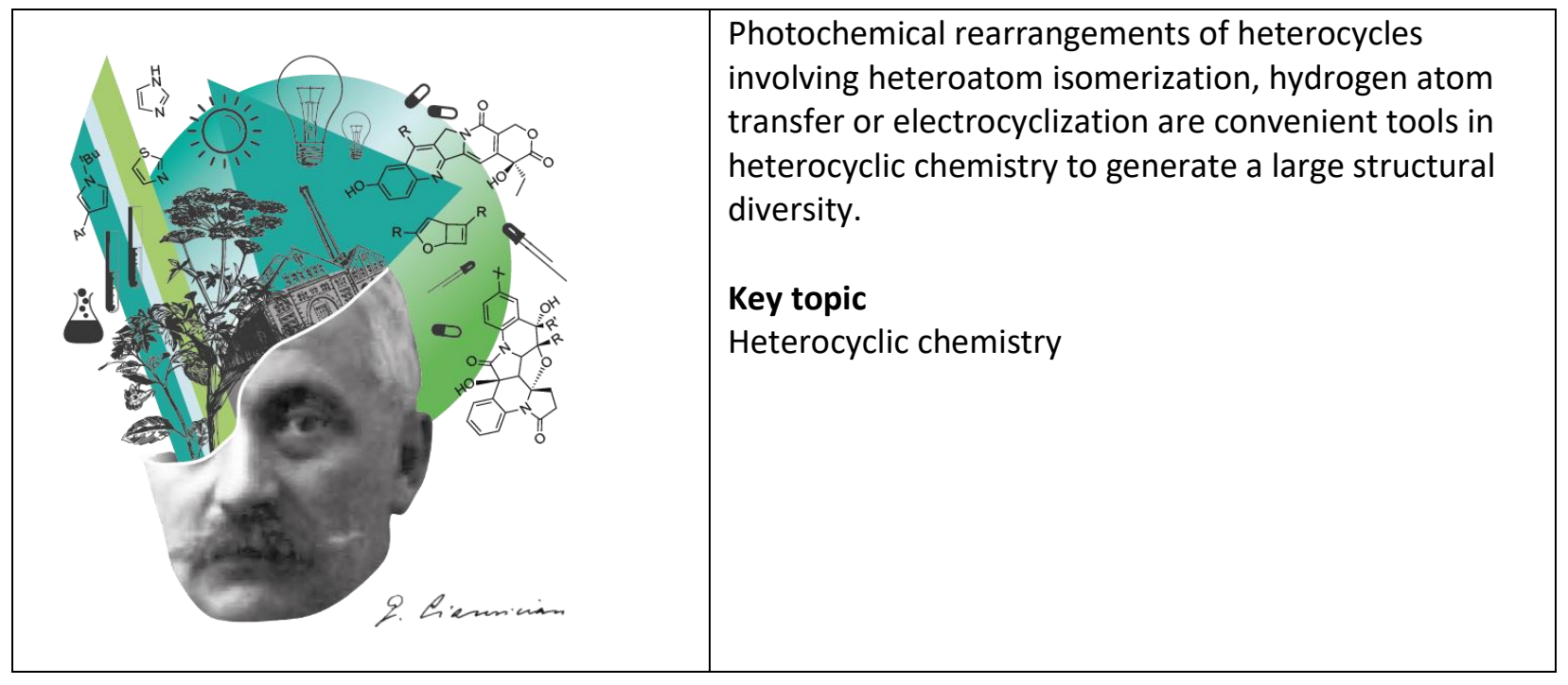




\section{Introduction}

Photochemical reactions are characterized by electronic excitation caused by light absorption. The change of electronic configuration causes a considerable change in chemical reactivity when compared to reactions at the ground state. ${ }^{1}$ For example, electron transfer is facilitated. A photochemical reaction can also be induced by energy transfer from the excited species. ${ }^{2},{ }^{3}$ These processes are now intensively investigated in connection with many applications to organic synthesis. ${ }^{4}$ These studies essentially contributed to the recent rebirth of synthetic organic photochemistry. The traditionally strong interaction between organic photochemistry and physical chemistry ${ }^{5}$ enables a high level of characterization and understanding of these reactions and particularly the mechanisms which also facilitate the optimization and application in various fields.

In connection with the electronic configuration change, very often typical characteristics such as regio or stereochemistry are inversed in photochemical reactions when compared to corresponding ground state reactions. Complex structures in a broader scope become more easily available. ${ }^{6}$ Typical examples are the di- $\pi$-methane rearrangement and corresponding heteroatom oxa- and aza-di- $\pi$-methane rearrangements. ${ }^{7}$ Often photochemical products possess an increased reactivity in particular the ground state reactions and can serve as interesting synthesis intermediates for natural product synthesis or for the preparation of new compounds in many fields such as pharmaceutical and agro-chemistry or for material sciences. In these domains, heterocyclic compounds play a key role. Access to new heteropolycyclic compounds is a daily challenge to fill the blanks in the chemical space. ${ }^{8}$-Often heterocyclic substituents are considered as bioisosteres ${ }^{9}$ in the context of a rational drug development. It should further be pointed out that the photon as a traceless reagent accounts for the green chemistry principles. ${ }^{10}, 11$

In this article, we would like to discuss photochemical rearrangements of heterocyclic compounds ${ }^{12}$, $^{13}$ involving heteroatom isomerization, hydrogen atom transfer (HAT) or electrocyclization.

\section{Photochemical heteroatom isomerization of heterocyclic compounds}

Photochemical reactions provide interesting tools to change the position of the heteroatoms or the substituents in heterocyclic compounds. In this way, the structural diversity is increased which is an important topic when new biologically active compounds are looked for. In material science such an approach is also interesting when heterocycles play a key role as building blocks. Typical examples are pyrazole and imidazole. The inhibition of the phosphodiesterase (PDE) 5 is increased when the pyrazole moiety in $\mathbf{1}$ is replaced by an imidazole ring in $\mathbf{2}$ (Figure 1). ${ }^{14}$ Similar effects have been observed for purin and corresponding pyrazol derivatives as inhibitors of RNA or DNA glycosilase activity of shiga toxin $1 .{ }^{15}$
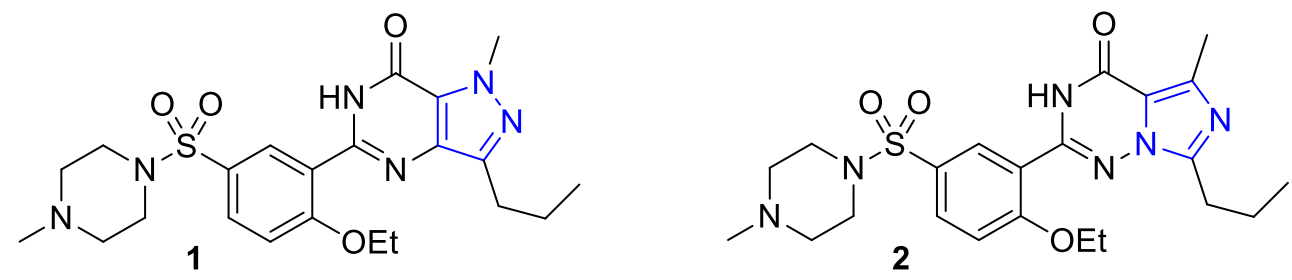

Figure 1. The pyrazol derivative 1 possesses a higher activity than the corresponding imidazole derivative $\mathbf{2}$. 
Since pyrazol and imidazole compounds are obtained by different synthetic approaches, a reaction enabling the systematic interconversion of derivatives of both compound families is highly appreciated. The member number of compounds families could be significantly increased. According to Scheme 1 in a photochemical reaction, pyrazols can be transformed into imidazols. ${ }^{16}$ Such reactions are part of the the larger family of circumabulatory rearrangements. ${ }^{17}$ Upon irradiation, the trimethylpyrazol derivative $\mathbf{3}$ is transformed into the imidazole derivatives 4 and $5 .{ }^{18}$ In a disrotatory $\left[\pi 2+_{\sigma} 2\right]$ electrocyclic reactions (blue arrows), the bicylic intermediate $\mathbf{6}$ is formed. 1,3-Sigmatopic shifts (red arrows) lead to the $\mathbf{7}$ and $\mathbf{8}$.

Intermediates $\mathbf{7}$ and $\mathbf{8}$ are transformed into the final products $\mathbf{5}$ and $\mathbf{4}$ respectively via disrotatory [ ${ }_{0} 2+_{\pi} 2$ ] electrocyclic reactions (blue arrows). Compound $\mathbf{5}$ can also be generated by homolytic cleavage of the $\mathrm{N}$ $\mathrm{N}$ bond in $\mathbf{3}$ leading to intermediates $\mathbf{9}$ and 10. Furthermore, it was observed that compound $\mathbf{4}$ can be transformed into 5 .
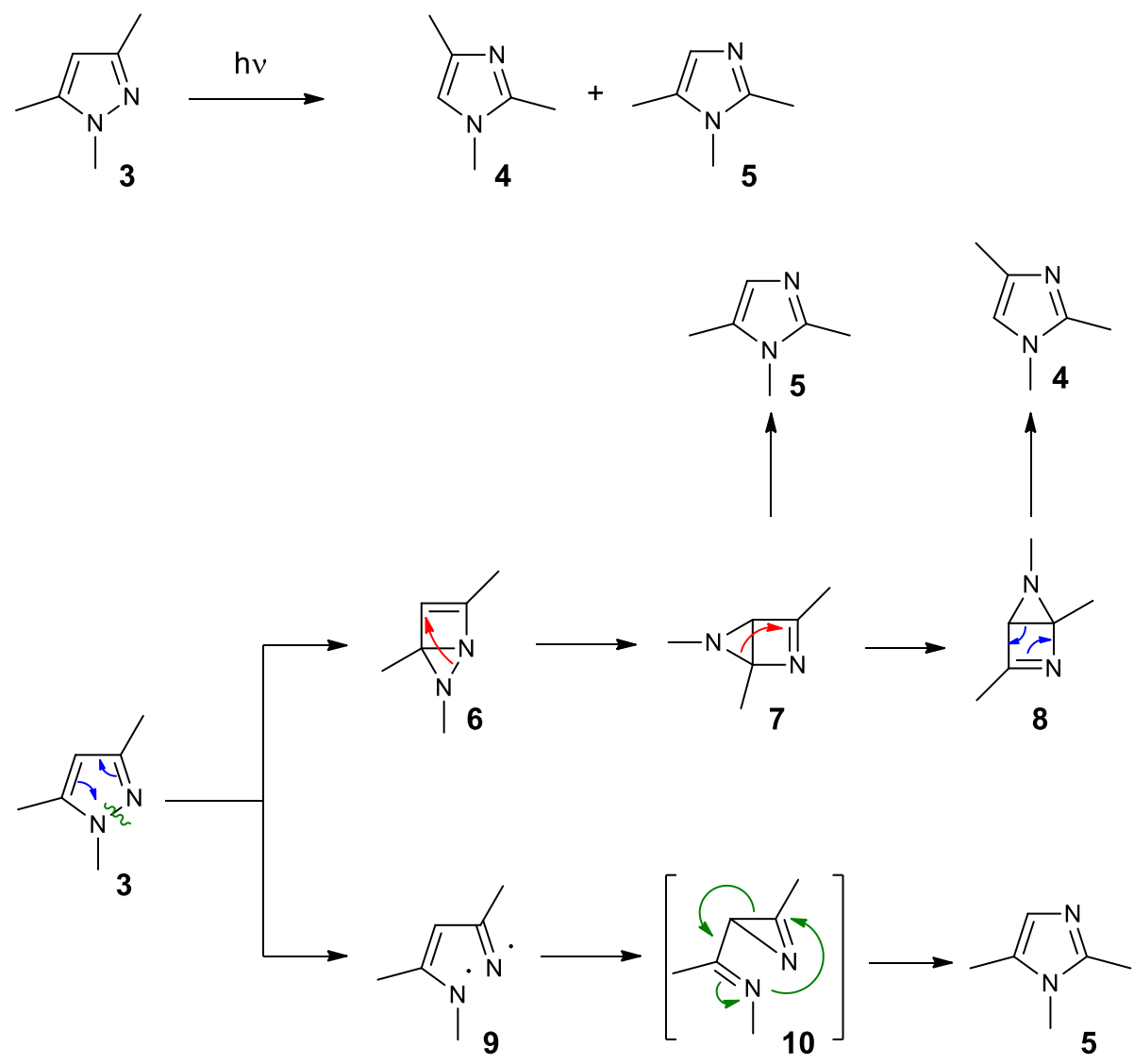

Scheme 1. Photochemical transformation of a pyrazol derivative into imidazoles.

The photochemical transformation of benzopyrazoles into the corresponding imidazole derivatives can efficiently be carried out (Scheme 2). ${ }^{19}$ Thus compounds 11 were transformed into the imidazole derivatives 12. The transformation of similar regioisomers $\mathbf{1 3}$ into $\mathbf{1 4}$ was more efficient. In fact, these pyrazol compounds possess a quinoid electronic structure. In the latter reaction the intermediates $\mathbf{1 5}$ and 16 has been discussed. ${ }^{20}$ When the irradiation was carried out at low temperature $\left(-60^{\circ} \mathrm{C}\right)$, 
compound 15 could be identified. Upon warmup, 15 gave 13 (not 14). Thus the final product 14 is formed from intermediate 16.<smiles>[R]c1n[nH]c2ccccc12</smiles>

$11 \mathrm{R}=\mathrm{Alk}, \mathrm{Ph}$<smiles>Pn1cc2ccccc2n1</smiles>

$13 \mathrm{R}=\mathrm{Alk}$<smiles>[R]c1nc2ccccc2[nH]1</smiles>

12<smiles>CC(C)[AsH3]</smiles>

14

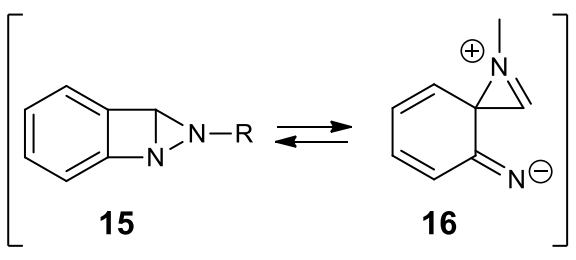

Scheme 2. Photochemical rearrangement of benzopyrazol derivatives into corresponding benzoimidazol derivatives. The irradiation has been carried out with high pressure Hg-vapor lamps.

Isoxazoles contain a nitrogen next to an oxygen atom. When compound $\mathbf{1 7}$ was irradiated at $\lambda=254 \mathrm{~nm}$, three compounds 18, 19 and 20 along with some benzoylacetone were isolated (Scheme 3). ${ }^{21} \mathrm{An}$ advanced mechanistic study revealed that the azirine $\mathbf{1 8}$ is an intermediate in the formation of the oxazoles 19 and 20. More interestingly, when 18 was irradiated at $300 \mathrm{~nm}$, the starting isoxazole $\mathbf{1 7}$ was obtained. In the first case, the formation of a zwitterion intermediate was suggested while in the second case, a diradical intermediate at the triplet state should be generated. By the way, this is an example which infringes the general accepted principle that the a photochemical reaction always occurs form the lowest excited singlet or triplet state as it was formulated in analogy with the Kasha and Vavilov roules (see ref.1, page 40). Especially in cases of intramolecular reactions which are faster than inter conversion processes, such infringes are observed.

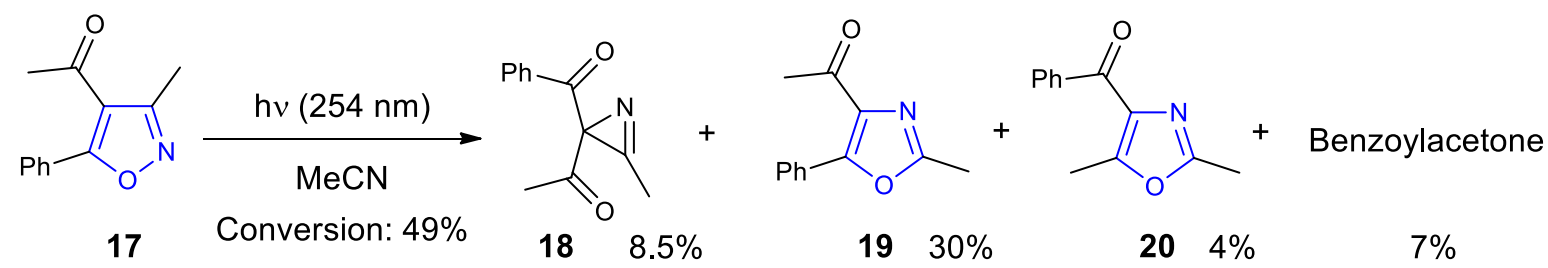

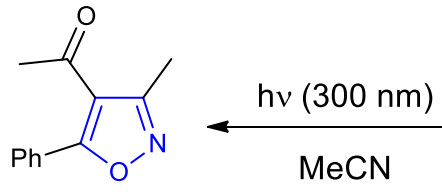

17

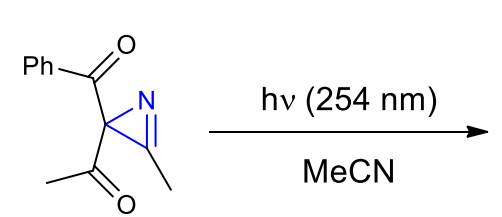

18<smiles>CC(=O)c1nc(C)oc1-c1ccccc1</smiles>

19<smiles>Cc1nc(C(=O)c2ccccc2)c(C)o1</smiles>

20

Scheme 3. Photochemical rearrangement of an isoxazol compound. 
Similar reactions have been carried out with benz- or naphthisoxazoles $\mathbf{2 1 a} \mathbf{a} \mathbf{b}$ (Scheme 4). ${ }^{22}$ Also in these cases, the spirocyclic azirine $\mathbf{2 2} \mathbf{a}, \mathbf{b}$ was detected as reaction intermediate. Photochemical or thermal rearrangement generates the final oxazole derivatives $\mathbf{2 3 a , b}$.

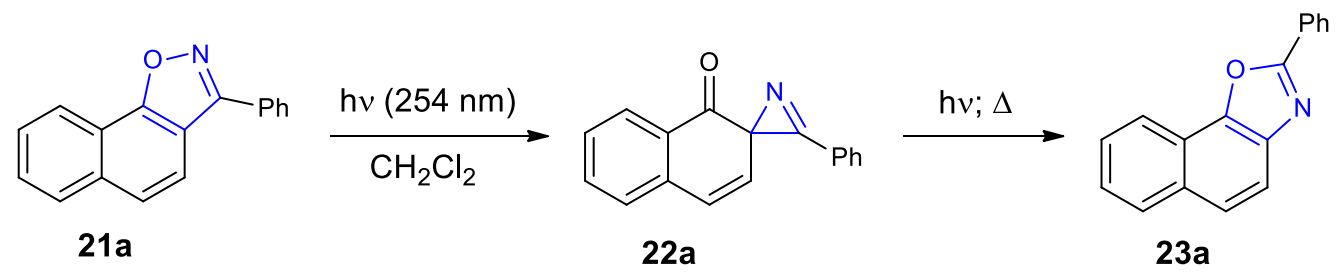

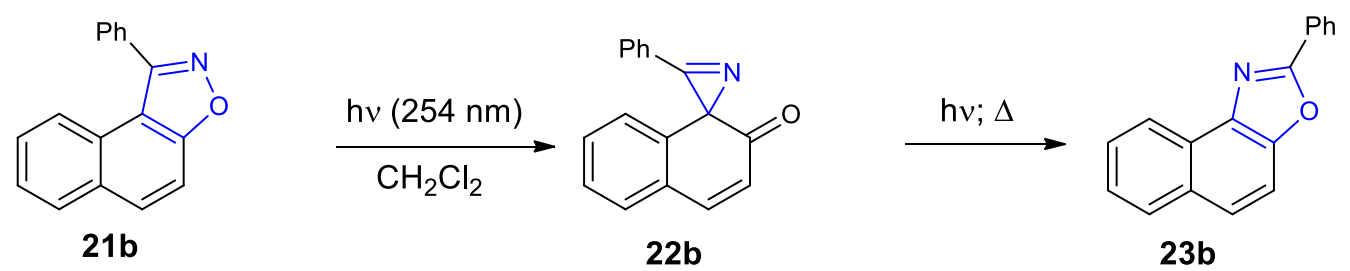

Scheme 4. Mechanistic study of the rearrangement of naphthisoxazoles.

The corresponding isothiazol 24 can be transformed into thiazol 25 (Scheme 5). ${ }^{23},{ }^{24}$ In an acidic media and when the heterocyclic compound is protonated at the nitrogen atom, the reaction is reversible. Under similar conditions, a migration of the substituents was also observed. Thus the photochemical transformation of $\mathbf{2 6}$ yields mainly $\mathbf{2 7}$ and lower amounts of $\mathbf{2 8} .{ }^{25}$ In the main reaction, the phenyl substituent migrates. In a computational study, it has been shown that bicylic intermediates are involved (compare 6-8 in Scheme 1). ${ }^{26}$ More generally in such reactions, a competition between this mechanism and mechanisms involving homolytic or heterolytic fragmentation of the bond between the two heteroatoms is discussed. ${ }^{27}$

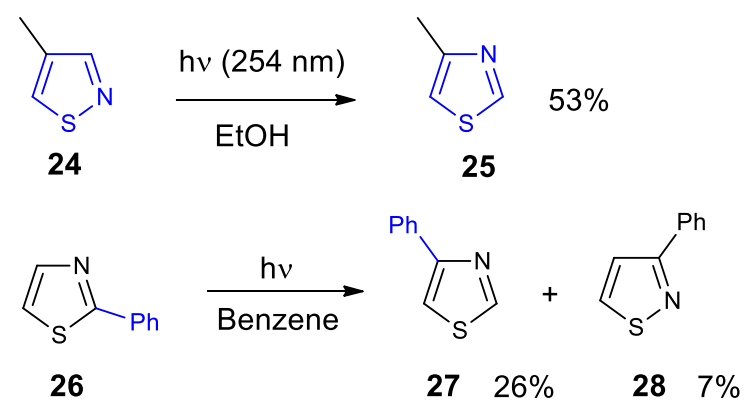

Scheme 5. Rearrangement of heteroatoms and migration of a substituent in isothiazole and thiazol derivatives.

Five membered heterocyclic aromatic compounds with three heteroatoms such as oxadiazoles are also very important structural elements in bioactive compounds and materials. ${ }^{28}$ In these compounds similar photochemical steps are observed. ${ }^{29}$ In particular, the cleavage of the $\mathrm{N}-\mathrm{O}$ bond is one of the first steps. ${ }^{30}$ Not only heteroatoms and substituents but also functional groups can migrate or be transformed. In the photochemical reaction of compound $\mathbf{2 9}$ to $\mathbf{3 0}$, a urea function is transformed into a 
carbamate (Scheme 6). ${ }^{31}$ Intermediates which are formed in such reactions can be trapped by an intramolecular addition which leads to rearranged heterocycles. Under mild reaction conditions, the isoxdiazole derivative $\mathbf{3 1}$ was transformed into triazol derivative $32 .{ }^{32} \mathrm{An}$ attack of amine nitrogen atom of the hydrazone on the nitrogen in 2 position (33) with formation of intermediate $\mathbf{3 4}$ was discussed as key step in this photochemical reaction.

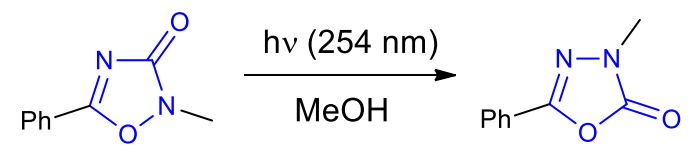

29

30

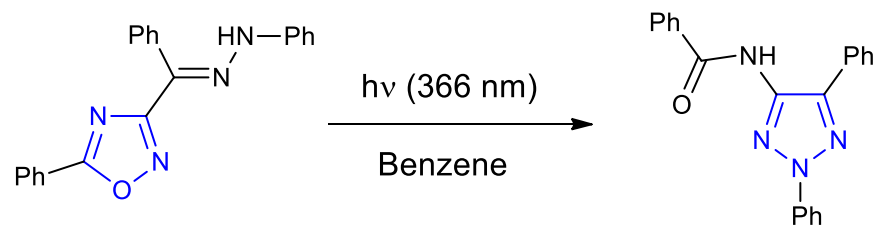

31

$3270 \%$

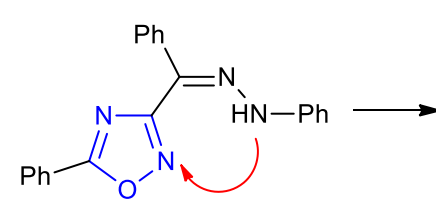

33

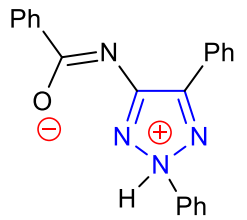

34

Scheme 6. Photochemical rearrangements with isoxadiazole derivatives.

Photoredox catalysis applied to organic synthesis considerably contributes to the renaissance of organic photochemistry. ${ }^{33}$ These conditions have also been applied to rearrangement reactions of heterocycles. When the isoxazolone derivative $\mathbf{3 5}$ is irradiated in the presence of the photoredox catalyst fac-Ir(ppy) the oxazol derivative $\mathbf{3 6}$ is obtained in high yield (Scheme 7). ${ }^{34}$ In this reaction, a decarboxylation step is involved. The rearrangement with ring extension (37) is a competitive process. Under optimized conditions using 4DPAIN as photocatalyst and triethyl amine as sacrificial electron donor, the latter process become the only reaction and compound $\mathbf{3 7}$ was isolated in good yields. Decarboxylation is suppressed by an electron transfer step because, in corresponding intermediate, a carboxyl radical is reduced to a carboxylate anion. The oxazole reaction was performed with 26 additional substrates and the oxazinone reaction (37) was pformed with seven additional derivatives. A similar study with corresponding thiocarbonyl derivatives have been carried using direct excitation, without photocatalysis. ${ }^{35} \mathrm{~A}$ variety of derivatives has been transformed in this way. 

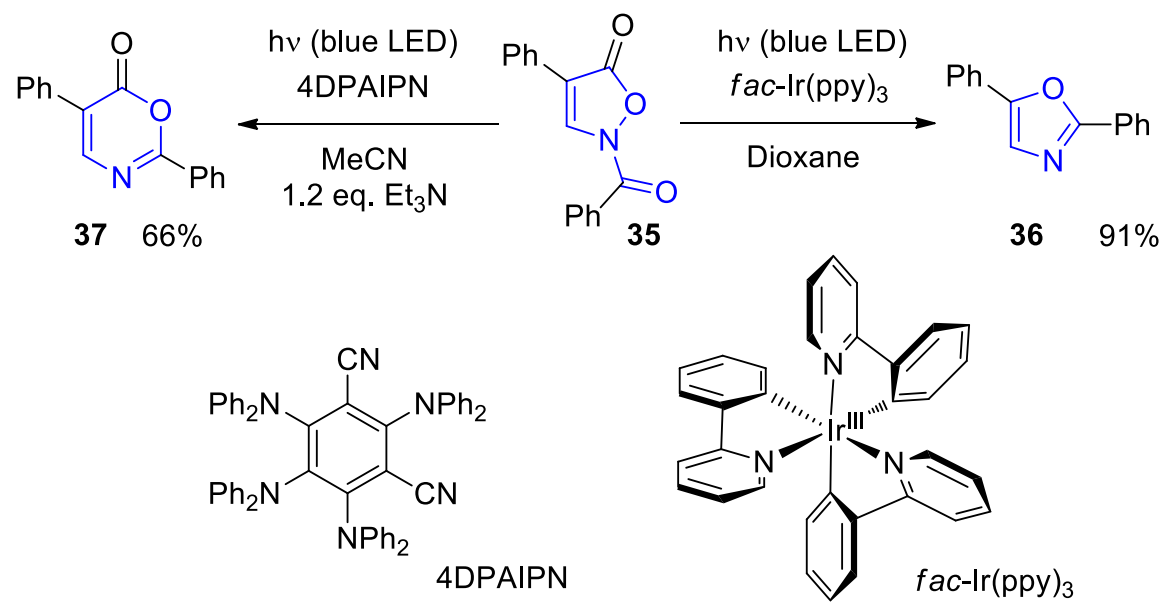

Scheme 7. Photoredox catalytic rearrangements of an isoxazolone derivative.

\section{Photochemical rearrangements induced by hydrogen atom transfer (HAT).}

In chemical ${ }^{36}$ and biological reactions ${ }^{37}$, hydrogen as the smallest and lightest atom, can easily be transferred. This transfer leads to the formation of high energy radical species that can rearrange or react with others species to form new molecules. Using photochemical HAT, the use of toxic or expensive chemicals can be avoided.

Photochemical 1,4-hydrogen abstraction is often observed. Pyrrole is a common heterocycle found in many natural products and drugs on the market. While this latter is easily accessible via photoredox catalysis, ${ }^{38}$ Some of them can be synthetized through direct irradiation from azetidinyl ketones such as 38 (Scheme 8). ${ }^{39}$ The reaction happens in a two steps mechanism ${ }^{40}$, where electron is transferred first from the nitrogen to the excited ketone (39) and then the proton follows $(\mathbf{4 0}, \mathbf{4 1})$. A dehydration is involved in the formation of the final product $\mathbf{4 3}$ from intermediate $\mathbf{4 2}$. It was shown that this photoreaction occurred at a triplet excited-state. A singlet excited-state could be involved when an alkyl instead of an aryl substituent is used. In this case, a Norrish type II photoelimination at the alkyl substituent takes place.

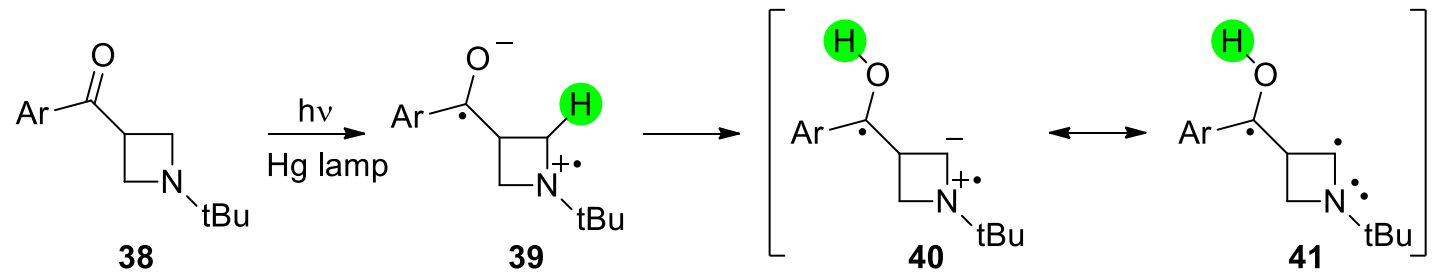<smiles>CC(C)(C)N1CC2C1C2(O)C(C)(C)C</smiles>

Scheme 8. Synthesis of pyrroles from azetidinyl ketones via 1,4-hydrogen abstraction. 
Another pathway to the synthesis of pyrroles has been proposed by Aoyama with thioamide derivatives. ${ }^{41}$ After direct irradiation, compound $\mathbf{4 4}$ undergoes 1,4-HAT to provide diradical $\mathbf{4 5}$ (Scheme 9). Radical combination leads to the intermediate $\mathbf{4 7}$. After elimination of $\mathrm{H}_{2} \mathrm{~S}$, the pyrrole derivative $\mathbf{4 9}$ is formed. The enamine derivative $\mathbf{4 6}$ is obtained by hydrogen transfer from thiol function into the 6 position. Small quantities of $\mathbf{4 6}$ are transformed into $\mathbf{4 8}$ by an electrocyclic reaction involving the aromatic substituent. The reactions of six different derivatives have been reported. This latter structure can be found in agrochemical fungicide. ${ }^{42}$

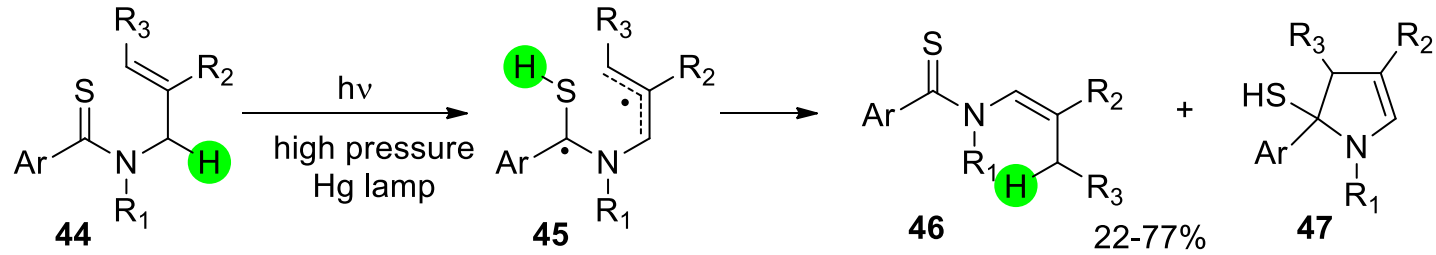<smiles>[R3]CC1([R2])c2cc([X])ccc2C(=S)N([R])C1[2H]</smiles>

Scheme 9. Synthesis of pyrroles from thioamides derivatives.

1,4-HAT is also employed as a key-step in the synthesis of bioactive natural products such as rocaglamides, forbaglins and aglains (Scheme 10). ${ }^{43}$ Such molecules are isolated from the plant Aglaia and are accessible via a subsequent dipolar cycloaddition. At the excited state, in the flavon compounds 50, hydrogen transfer occurs. ${ }^{44}$ Such reaction steps are also discussed in the context of phototautomerisation. The resulting intermediates $\mathbf{5 1}$ undergoes cycloaddition leading adducts such as compounds 52. A ketol rearrangement yields compounds 53 and 54. 


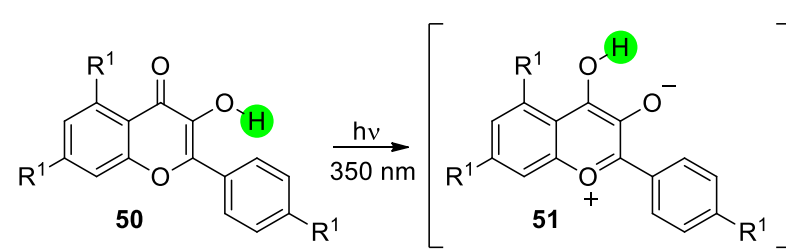

$\mathrm{R}^{1}=\mathrm{H}, \mathrm{OMe}$

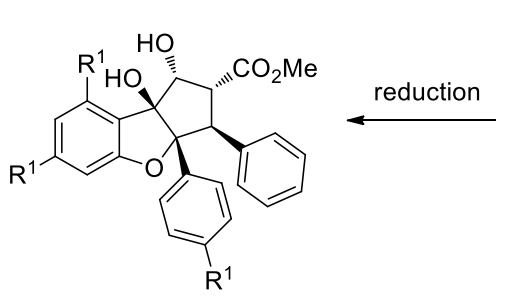

$R^{1}=H$, yield : $95 \%$

$\mathrm{R}^{1}=$ OMe, yield : $55 \%$

Rocaglamide core

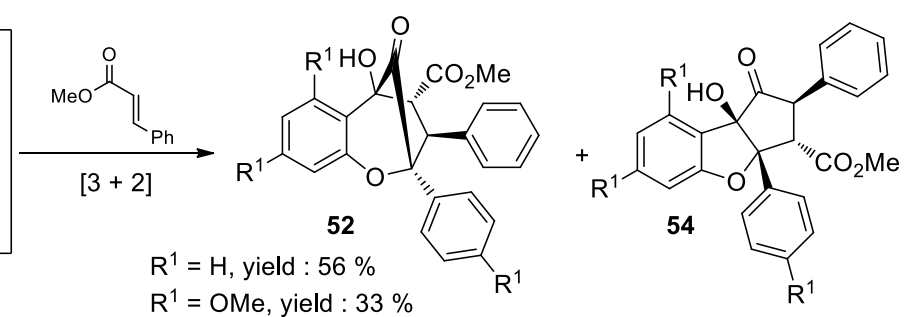

$\mathrm{R}^{1}=$ OMe, yield : $33 \%$

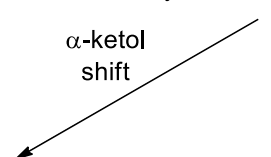

$\mathrm{R}^{1}=\mathrm{H}$, yield : $14 \%$

oxydation

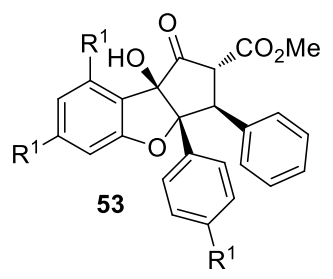

$\mathrm{R}^{1}=\mathrm{H}$, yield : $45 \%$

$\mathrm{R}^{1}=$ OMe, yield : $95 \%$

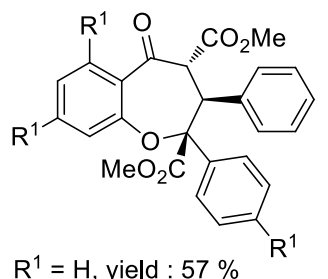

Forbaglin core

Scheme 10. Formation of bioactive natural compounds core of forbaglin and rocaglamide via 1,4-HAT and [3+2] cycloaddition.

Enantioselective HAT has also been carried out recently. ${ }^{45} \mathrm{~A}$ study of Xia et al. showed the possibility to use 3-hydroxyquinolinones instead of 3-hydroxychromenones to make this photoreaction. ${ }^{46}$

Natural compounds can be synthetized through photoinduced 1,5-HAT. Wender et al. proposed a photochemical access to a precursor of taxol C,D ring system (Scheme 11, equation 1). ${ }^{47}$ Subsequent photoenolization from 1,5-HAT is also possible prior to cycloaddition (equation 2). ${ }^{48}$ This was performed to the synthesis of anti-tumor drugs Pleurotin. ${ }^{49}$ More recently, Reddy et al. used this photochemical cascade towards the synthesis of pyrroloquinazoline core of Vasicinone and Luotonins, bioactive natural products (equation 3). ${ }^{50}$ 


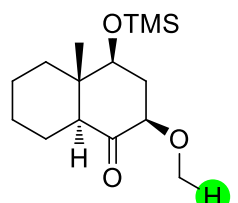

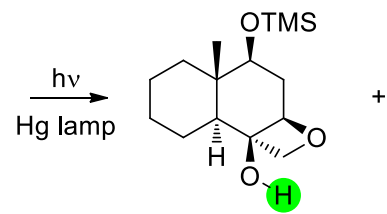

$32 \%$

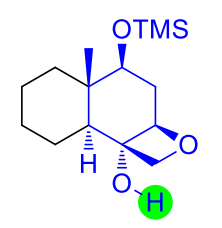

$11 \%$ (eq. 1)

(eq. 2)

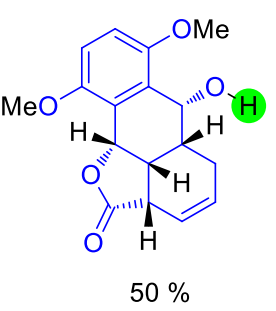<smiles>CC(=O)[C@]1(O)C=Cc2nc3ccccc3c(=O)n21</smiles>

(eq. 3)<smiles>O=c1c2ccccc2nc2n1CCC2O</smiles>

Vasicinone

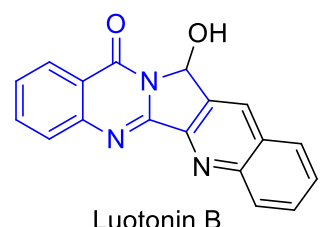

Scheme 11. - Synthesis of precursors of natural products Taxol, Pleurotin, Vasicinone and Luotonin B.

Kutateladze's team developed a strategy to use a highly stereoselective photoreaction for the synthesis of complex polyheterocycles. Enol/imine intermediates $\mathbf{5 6}$ are generated by photoinduced 1,5-HAT (Scheme 12). ${ }^{51},{ }^{52}$ After hydrogen abstraction, a [4 + 2] cycloaddition leads to the formation of $\mathbf{5 7}$ and a $[4+4]$ cycloaddition generates the oxamorpham core $\mathbf{5 8}$ from compound $\mathbf{5 5}$. The same reaction mechanism is involved in the formation of $\mathbf{6 0}$ and $\mathbf{6 1}$ from 59. It should be pointed out that in the case of the photoadducts obtained from $\mathbf{5 5}$, a Suzuki reaction is carried out. Such photochemical hydrogen atom or proton transfer processes between heteroatoms like oxygen or nitrogen (see also Scheme 10) are also discussed in the context of excited state intramolecular proton transfer (ESIPT). ${ }^{53}$ 


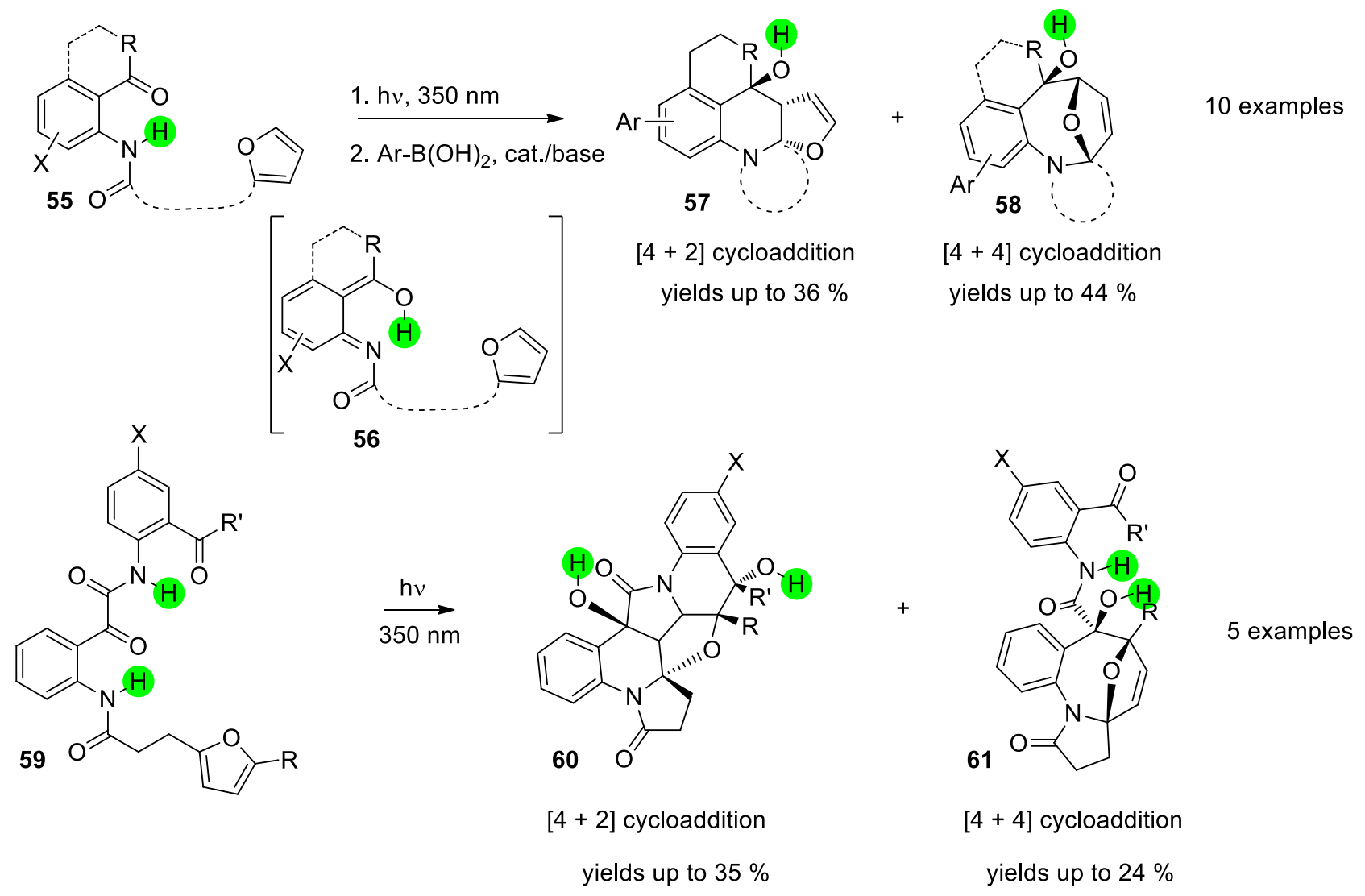

Scheme 12. Formation of polyheterocycles via photoenolisation.

Nitrogen-containing heterocycles are ubiquitous in nature. ${ }^{54}$ Many efforts are carried out by synthetic chemists to produce new azaheterocyclic building-blocks to feed pharmaceutical market as they have a big presence in it. ${ }^{55}$ Photoinduced hydrogen abstraction can be carried out on $\mathrm{N}$-heterocycles to access interesting compounds. After irradiation of molecule 62, compound $\mathbf{6 3}$ is obtained due to [2+2] cycloaddition followed by a photochemical rearrangement (Scheme 13).$^{6}$ Longer irradiation triggers 1,5 HAT leading to the intermediate 64 . The transformation to compound 65 , a bridged azocanone, resembles to the Norrish type II reaction. This kind of core stucture is found in synthetic precursors of alkaloids such as strictamine, rhazinoline, melinonine and strychnoxanthine. ${ }^{57,58}$ 

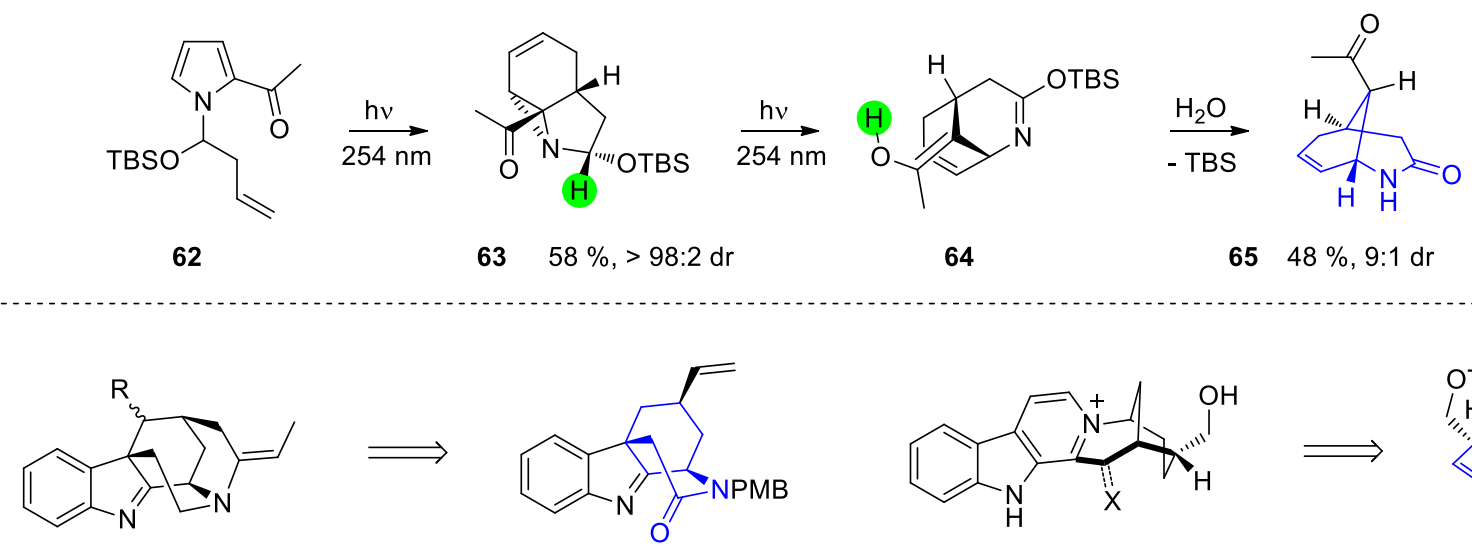

$(-)$-Strictamine $: \mathrm{R}=\beta-\mathrm{CO}_{2} \mathrm{Me}$

$(-)$-Rhazinoline : $\mathrm{R}=\alpha-\mathrm{CHO}$

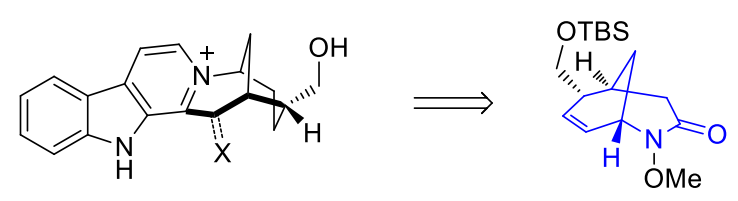

(-)-Melinonine-E : $\mathrm{X}=\mathrm{H}$

$(+)$-Strychnoxanthine : $\mathrm{X}=\mathrm{O}$

Scheme 13. Formation of a bridged azocanone: potential precursor for the synthesis of alkaloid structures.

Hoffmann's group proposed a way of synthetizing a trifluoromethyl substituted pyrrolo-oxazolone (Scheme 14). ${ }^{59}$ In this study, they show the regioselectivity of photoinduced HAT. In contrary of previous research with furanone derivatives, ${ }^{60}$ they found that reaction selectivity is not induced in the HAT step, but in the cyclisation step. Two compound families resulting either from the formation of a C-C bond (67 and 68 ) or a $\mathrm{C}-\mathrm{N}$ bond $\mathbf{6 9}$ can be obtained in good yield from the reaction of oxazolone derivatives $\mathbf{6 6 .}$ This latter compound is a core structure of molecules used for diabetes treating. ${ }^{61}$<smiles>CC1(CCC2(C(F)(F)F)N=C(c3ccccc3)O2)OCC(=O)O1</smiles>

66

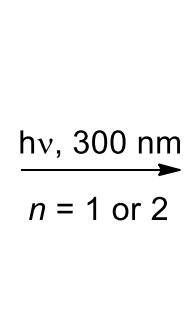

L

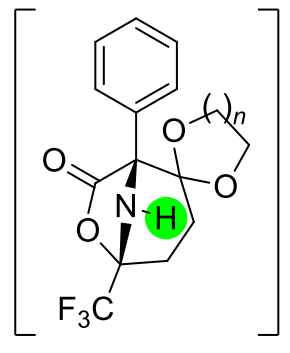

$67 n=1: 0 \%$ $n=2: 38 \%$<smiles>CC(C)(C)C1CCC2(OCCO2)C(c2ccccc2)=N1</smiles>

$68 \begin{aligned} & n=1: 22 \% \\ & n=2: 32 \%\end{aligned}$<smiles>O=C1OC23C(=O)OC(C(F)(F)F)(CCC24OCCO4)N3C1c1ccccc1</smiles>

$69 n=1: 33 \%$ $n=2: 0 \%$

Scheme 14. Photoinduced intramolecular radical cyclisation via 1,5-HAT with imines. 
1,6-Hydrogen abstraction has frequently been applied to natural product synthesis. Natural molecules are a source of potential drug leads. From mankind's origin to nowadays, therapeutic treatments is mainly based on molecular structures from fauna and flora molecular wealth. It is estimated that only around $36 \%$ of new chemical entities for drugs are not based or inspired by natural products. ${ }^{62}$ Among the latters, alkaloid synthesis has been highlighted as their group is wide and offers numerous biological properties (Scheme 15). ${ }^{63}$ Gramain et al. succeeded in making Isoretronecanol via photoinduced 1,6HAT. ${ }^{64}$ In this photochemical key step, the pyrrolidine derivative $\mathbf{7 0}$ was transformed into the bicyclic lactam 71. Isoretronecanol a pyrrolizidine type alkaloid found in various plant species. Wu et al. proposed a similar pathway to the synthesis of alkaloid-like benzopyrrolizidine structure, found in Linamycins. ${ }^{65}$ In this synthesis, 72 was transformed into 73 via a 1,6-hydrogen transfer.<smiles>CC(=O)CC(=O)N1CCC[C@H]1C</smiles>

70

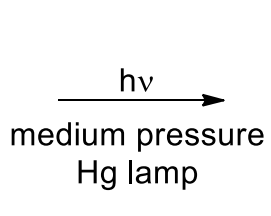

(a)<smiles>COC(=O)C1(O)CC(=O)N2CCCC21</smiles>

$7170 \%$<smiles>[R]C1N2C(=O)c3ccccc3[C@]2([R])C[C@@]1([R])OC</smiles>

7312 examples yields up to $87 \%$

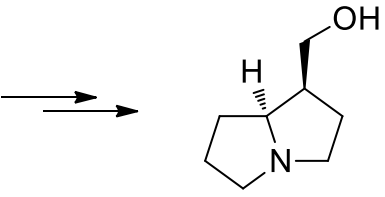

Isoretronecanol<smiles></smiles>

example of a Linamycin alkaloid

Scheme 15. Access to Isoretronecanol and Linamycin core via 1,6-HAT.

Others precursors of natural products are accessible via 1,6-HAT like Combrenin, ${ }^{66}$ Lurbinectedin, ${ }^{67}$ Tawianiaquinol A, ${ }^{68}$ Pauwlonin, ${ }^{69}$ Coumestan, Coumestrol, $^{70}$ and Aflatoxins ${ }^{71}$ (Scheme 16). 


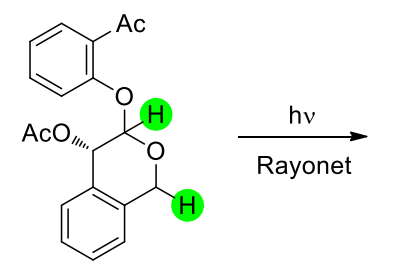

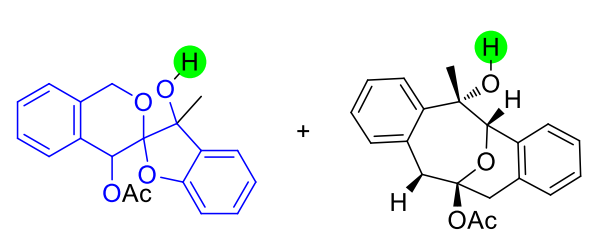

via 1,6-HAT

$10 \%$

$10 \%$ via 1,8-HAT

$24 \%$<smiles>CC1=C(OCc2ccccc2)C(=O)C2=C(C[C@H](C)N(C(=O)OCc3ccccc3)C2Cc2ccccc2)C1=O</smiles><smiles>CC(C)C1=C(OC[Hg])C(=O)C2=C(C1=O)[C@H](C=O)[C@]1(C)CCCC(C)(C)[C@@]1(C)C2</smiles><smiles>[Mg][Mg][Mg]</smiles><smiles>[2H]c1c2c(c3c(c1C(C)C)C(C)C1C(CCCC1(C)C)C3C)OCO2</smiles>

Taiwaniaquinol $\mathrm{A}$ $30 \%$<smiles>[O][C@@H](OCC1C(=O)CO[C@H]1c1ccc2c(c1)OCO2)c1ccc2c(c1)OCO2</smiles><smiles>Cc1c(O)c2c(c3c1OCO3)N(C(=O)OC(C)(C)C)C(CO)[C@H](C)C2</smiles>

$84 \%$

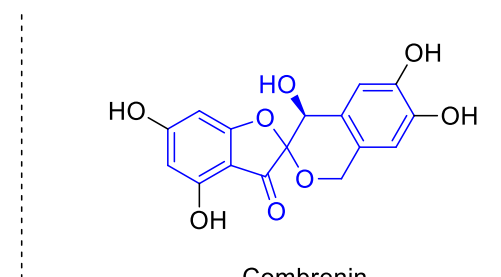

Combrenin

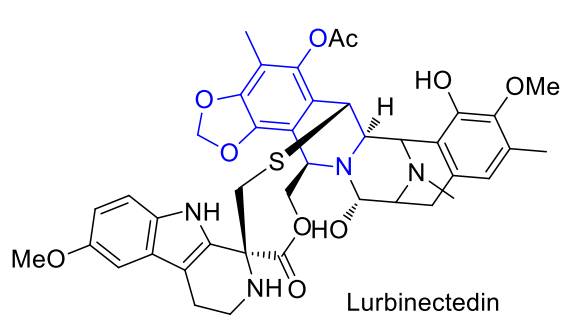

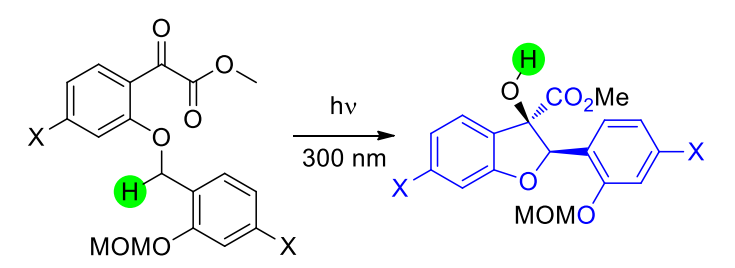<smiles>[B]C(OC)Oc1cccc(OCOC)c1C(=O)CCO</smiles>

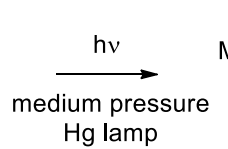<smiles>COCc1cccc2c1OC(OC)C2([O])CCO</smiles>

$30 \%$

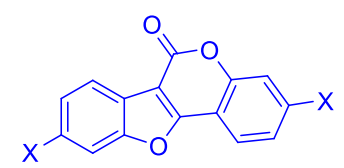

Coumestan : $\mathrm{X}=\mathrm{H}: 45 \%$ Coumestrol : $X=\mathrm{OMe}: 75 \%$

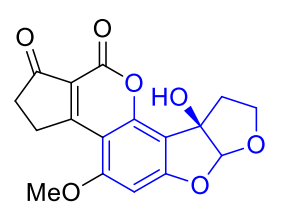

Aflatoxin M2

Scheme 16. Synthesis of various precursors of natural products via 1,6-HAT.

Macrocyclizations via photoinduced hydrogen transfer has been intensively studied with phthalimides systems. ${ }^{72},{ }^{73},{ }^{74} \mathrm{Hu}$ et al. proposed another system to carry out $1, n$-HAT (Scheme 17). ${ }^{75}$ After irradiation of 74 an electron is transferred to the excited ketone, followed by a proton. The mechanism of transferring 
hydrogen unfolds in two-steps..$^{40}$ Macrocyclization then occurs by recombination to 75 . In the same year, Yamazaki et al. succeeded in making oxathiocanone core $\mathbf{7 7}$ from $\mathbf{7 6}$ with the same reaction involving two-steps mechanism for the hydrogen atom transfer. ${ }^{76}$

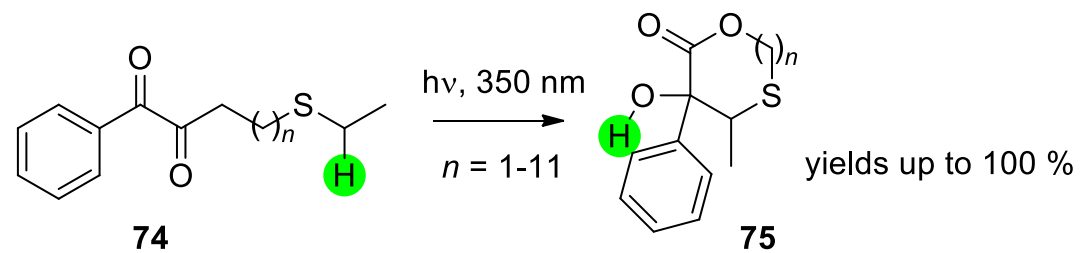<smiles>[R]C([R])([R])SCCOC(=O)CC(=O)c1ccccc1</smiles>

76

77

Scheme 17. Macrocyclization with thioether derivatives via hydrogen atom transfer.

Other examples of macrocyclization via $1, n$-HAT have been reported in connection with studies on ketoprofen-quencher conjugates $\mathbf{7 8}$ and benzophenone-methionine dyads $\mathbf{7 9}$ (Scheme 18), ${ }^{77,78,79}$ These studies mimic and highlight stereodifferentiating interactions between photosensitizing drugs and macromolecular structures in the excited state in order to understand mechanistic overviews of reaction steps in biological systems.<smiles>CC(C(=O)NCC1CC[C@H](O)O1)c1cccc(C(=O)c2ccccc2)c1</smiles><smiles></smiles>

yield up to $80 \%$<smiles>O=C(c1ccccc1)c1ccc(CC2NC(=O)C(CCSC[Hg])NC2=O)cc1</smiles><smiles>O=C1NC2Cc3ccc(cc3)C(O)(c3ccccc3)CSCCC1NC2=O</smiles>

$33 \%$

Scheme 18. Examples of 1,12-HAT and 1,15-HAT for macrocyclization. 


\section{Electrocyclization reactions with pyridine derivatives}

Taylor and Paudler reported that substituted pyridones are rapidly converted by UV light irradiation to a solid dimer which reverts to the original pyridone upon heating above its melting point. ${ }^{80}$ Only a few years later, in 1964, Corey and Streith studied the photoreactivity of $\mathbf{N}$-methyl-2-pyridone $\mathbf{8 0}$ (Scheme 19). ${ }^{81}$ Irradiation of diluted solutions of these compounds at $-20^{\circ} \mathrm{C}$ led to the corresponding bicyclic isomers 81.

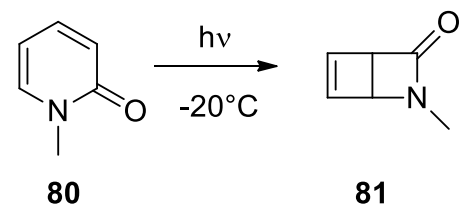

Scheme 19. Photochemical electrocyclization N-methylpyridone 80.

Photopyridone's relative stabilities were then intensively discussed during the 70's. De Selms and Schleigh concluded that unsubstituted photoisomers, are relatively unstable. ${ }^{82}$ However, substituted 2pyridones led to relatively high degree of stability of the corresponding photopyridones. ${ }^{81}$ In a more exhaustive publication, Furrer obtained similar results and proved the high thermal stability of the resulting photoproducts. ${ }^{83}$

Asymmetric electrocyclization reactions induced by irradiation of 2-pyridones using chiral auxiliarities were also reported by Sato et al. ${ }^{84}$ The authors used enantiomerically pure 4-menthyloxy pyridone 82 (Scheme 20). A variety of enantiomerically pure $\beta$-lactam derivatives with antibacterial activities are available with this reaction.
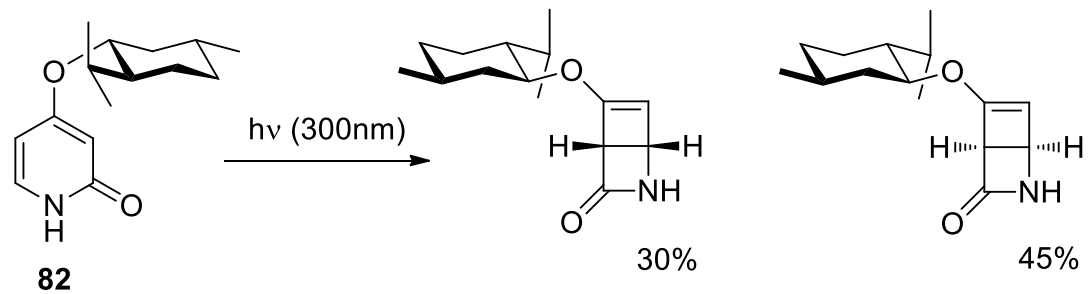

Scheme 20. Asymmetric electrocyclization of a pyridine derivative.

The reaction is also used for the synthesis of more complex heterocyclic compounds. Thus Tsichiya et al. reported the synthesis of 1,4-oxazepinones $\mathbf{8 4}$ and 1,4-diazepinones 85 from $\mathbf{~}$-protected 2-pyridones 83, using photochemical and thermal rearrangements (Scheme 21 ).${ }^{85}$ In this reaction sequence, a heteroatom is inserted between the 4 and 5 position. 


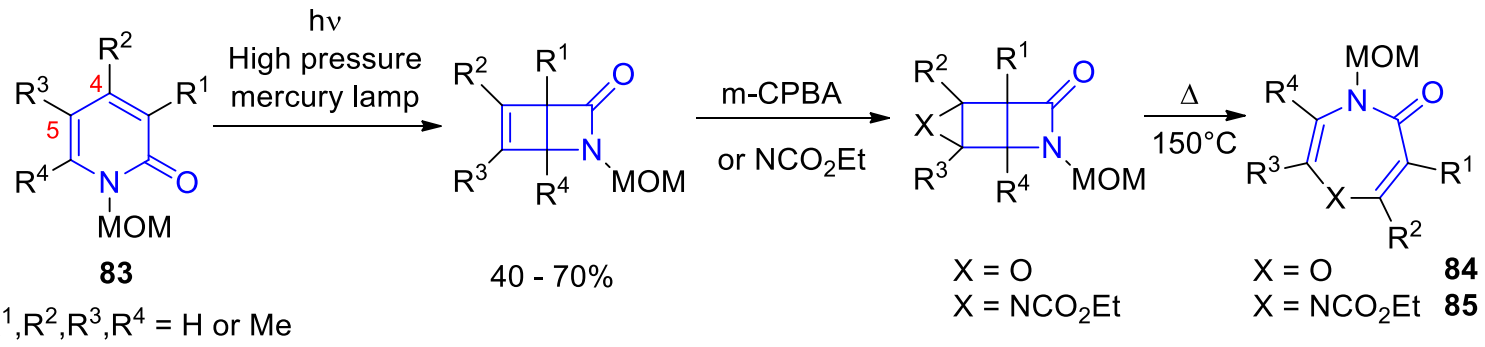

Scheme 21. Synthesis of 7 membered heterocycles using the photochemical electrocylization of pyridines.

Although the chromophore of pyridinium salts resembles to that one of pyridones, the photoreactivity is different. In these compounds an electrocyclic reaction is observed involving postions 2 and 6 . Such reactions were first studied during the 70 's by Kaplan et al. ${ }^{86}$ Upon irradiation methylpyridinium chloride 86 in aqueous $\mathrm{KOH}$ led to stereoselective formation of the aziridine containing bicyclic allylic alcohol 87 (Scheme 22). Intermediate $\mathbf{8 8}$ results from a photochemical electrocyclization. When treated under acidic or similar conditions, the aziridine ring is opened. Bennet et al. obtained the 6azabicyclo[3.1.0] hexenol compound $\mathbf{9 0}$ from the photochemical transformation of $89 .{ }^{87}$ Further transformations yielded a corresponding cyclopentenylamine derivative $\mathbf{9 1}$. Which was transformed into the bicyclo[3.1.0] hexane scaffold 92. These compounds act as a mimic of a distorted sialic acid bound in the neuraminidase active site. Using continuous flow technology, the photochemical reaction was carried out on multi gram scale with a productivity of $3.7 \mathrm{~g} \mathrm{~L}^{-1} \mathrm{~h}^{-1} .88$

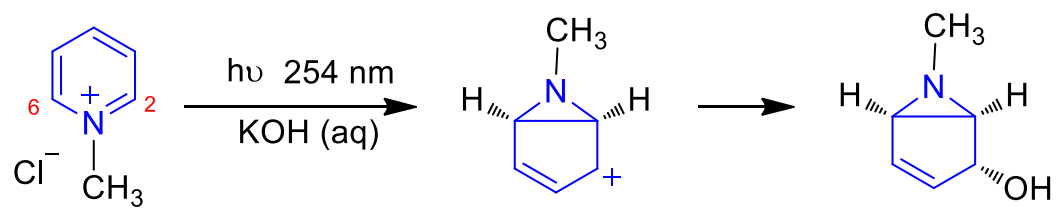

86

88

87

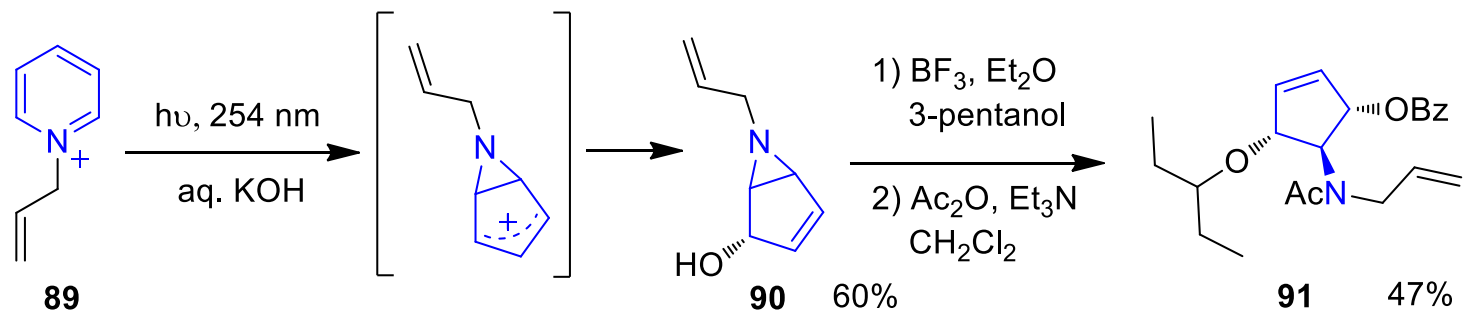<smiles>[R]N[C@H]1[C@@H](N)[C@@H](OC(CC)CC)[C@@H]2[C@H](C(=O)O)[C@@H]21</smiles>

Scheme 22. Photochemical electrocyclization of a pyrdinium salts. 
The photochemical pathway gives an attractive approach, leading to versatile intermediate compounds which can be used for the total synthesis of molecules such as mannostantin A, trehazolin derivatives ${ }^{89}$, cephalotaxine ${ }^{90}$ or even Lactacystin ${ }^{91}$ (Figure 2). Mechanistic and theoretical studies performed by Damiano et al. explain in details how the irradiation of pyridinium salts provides the stereocontrolled synthesis of a huge range of molecular structures such as bicyclic aziridines, fused heterocycles and functionalised aminocyclopentenes. ${ }^{90}$<smiles>C[C@@H]1[C@H](N)[C@H](O)[C@H](O)[C@H]1O</smiles>

Mannostantin A<smiles>[R6]C1C(OC)=CC23CCCN2CCc2cc4c(cc2[C@]13C)OCO4</smiles>

(-)-Cephalotaxine<smiles>OC[C@H]1O[C@@H](NC2=N[C@@H]3[C@@H](O2)[C@H](O)[C@@H](O)C3(O)CO)[C@H](O)[C@@H](O)[C@@H]1O</smiles>

Trehazolin<smiles>CC(=O)N[C@@H](CSC(=O)[C@]1(C(O)C(C)C)NC(=O)[C@H](C)[C@@H]1O)C(=O)O</smiles>

Lactacystin

Figure 2. Natural product targets which are accessible by a photochemical electrocyclization of pyridinium precursors.

The reaction was also carried out with complex compounds. Using the stereoselective properties of these photochemical reactions, Hanaoka et al. first showed that it was possible to stereoselectively synthesize fumariline (an alkaloid isolated from Fumaria officinalis), involving an electrocyclization with phenol betaine 93 which was obtained from protoberberine (Scheme 23). ${ }^{92}$<smiles></smiles>

Protoberberine<smiles>Oc1c2c(ccc3c[n+]4c(c1-3)OCO4)CCc1cc3c(cc1-2)OCO3</smiles>

93

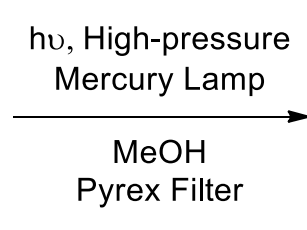

$64 \%$<smiles></smiles>

8,14-Cycloberberine

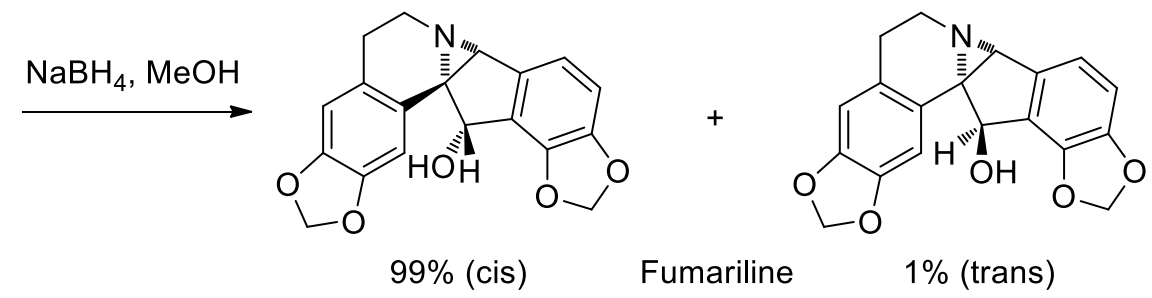

Scheme 23. Photochemical electrocyclization applied to the synthesis of fumariline. 
Pyridine $\mathrm{N}$-imides are related chromophores. Using photochemical electrocyclization, Kojima et al. reported the first synthesis of simple monocyclic 1,3-diazepines from 1,2-diazepines (Scheme 24). ${ }^{93}$ Photoisomerization of 3-substituted pyridine $\mathrm{N}$-imides $\mathbf{9 4}$, yields to the corresponding 4 - and 6substituted $1 \mathrm{H}$-1,2-diazepines $\mathbf{9 5 a}$ and $\mathbf{9 5 b}$. Further irradiation leads to the formation of 2,3diazabicyclo[3.2.0]hepta-3,6-dienes 96. Additional heterocyclic compounds can be obtained when thermal reactions are carried out. Thus the $1 H$-1,2-diazepines $95 \mathrm{a}, \mathbf{b}$ are transformed into the corresponding $1 \mathrm{H}-1,3$-diazepane compounds $\mathbf{9 7 a , b}$ by heating. A photochemical transformation of the latter compounds yields again 2,3-diazabicyclo[3.2.0]hepta-3,6-dienes $\mathbf{9 8}$ which are regioisomers of $\mathbf{9 6 .}$ All these compounds can selectively been prepared by optimizing the reaction conditions.

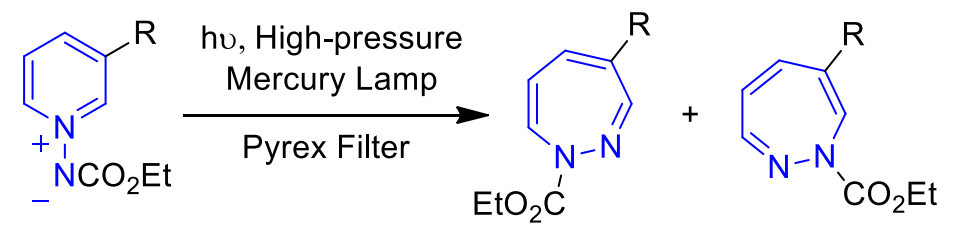

$94 \mathrm{R}^{1}, \mathrm{R}^{2}=\mathrm{Me}$ or $\mathrm{H} \quad$ 95a $\quad 60-70 \% \quad$ 95b $\quad 20-30 \%$

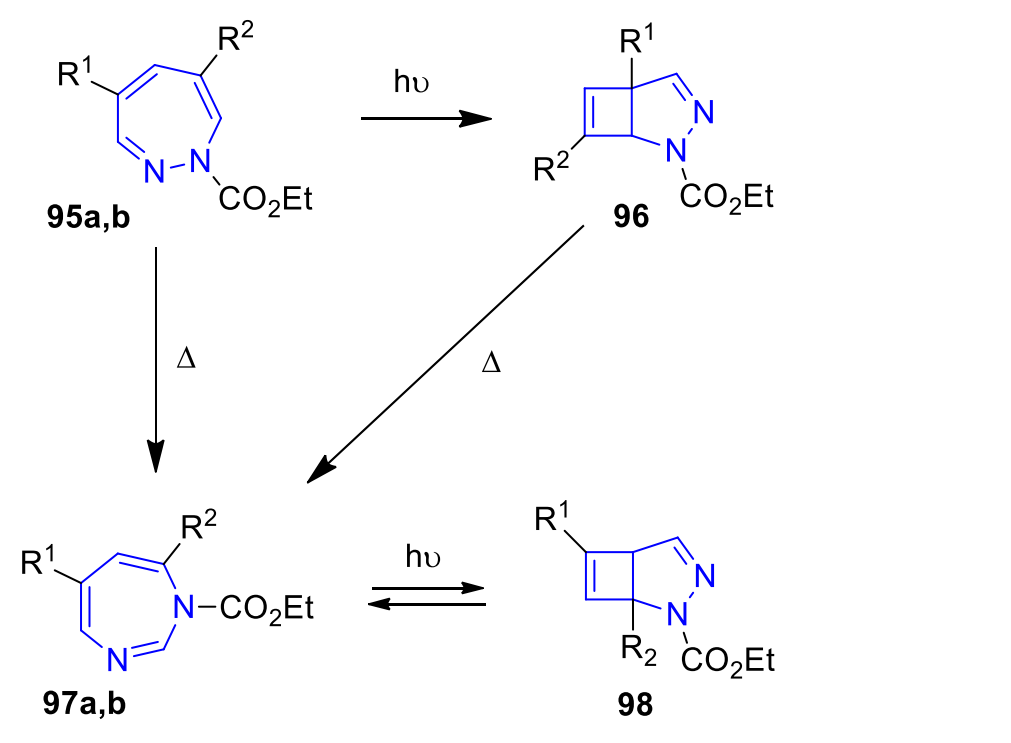

Scheme 24. Photochemical and thermal reactions starting with pyridine $\mathrm{N}$-imides.

\section{Conclusion}

As in many cases of organic photochemical reactions, a systematic scope exploitation of photochemical reactions of heterocyclic compounds has rarely been performed in the past. This is deplorable since such reactions are of high interest in the research of biologically active compounds and many other domains. Photochemical heteroatom isomerization of the heteroatoms or substituents as well as electrocyclization and hydrogen atom transfer reactions considerably enlarge the access to different heterocyclic compounds. During recent years, new techniques have been developed such as LED lamps 
or continuous flow techniques adapted to photochemical reactions. Also photoredox catalysis offers numerous new possibilities for the transformation of heterocyclic compounds. This research domain should be revisited by the photochemical and organic chemists' communities.

${ }^{1}$ P. Klán, J. Wirz, Photochemistry of Organic Compounds, Wiley, Chichester, 2009.

2 J. A. Dantas, J. T. M. Correia, M. W. X. Paixão, A. G. Corrêa, ChemPhotoChem 2019, 3, DOI

10.1002/cptc. 201900044

${ }^{3}$ C. Michelin, N. Hoffmann, ACS Catal. 2018, 8, 12046.

${ }^{4}$ W. Liu, C.-J. Li, Synlett 2017, 28, 2714.

${ }^{5}$ M. Oelgemöller, N. Hoffmann, Org. Biomol. Chem. 2016, 14, 7392. L. Buzzetti, G. E. M. Crisenza, P. Melchiorre, Angew. Chem. Int. Ed. 2019, 58, 3730.

${ }^{6}$ N. Hoffmann, Chem. Rev. 2008, 108, 1052. T. Bach, J. P. Hehn, Angew. Chem. Int. Ed. 2011, $50,1000$.

${ }^{7}$ E. Riguet, N. Hoffmann, in Comprehensive Organic Synthesis, $2^{\text {nd }}$ Ed., Vol. 5 (Eds.: P. Knochel, G. A. Molander), Elsevier, Amsterdam, 2014, pp. 200-221.

${ }^{8}$ A. M. Virshup, J. Contreras-García, P. Wipf, W. Yang, D. N. Beratan, J. Am. Chem. Soc. 2013, $135,7296$.

${ }^{9}$ Bioisosteres in Medicinal Chemistry (Ed.: N. Brown), Wiley-VCH, Weinheim, 2012.

10 N. Hoffmann, Photochem. Photobiol. Sci. 2012, 11, 1613.

${ }^{11}$ A. Albini, M. Fagnoni, Green Chem. 2004, 6, 1.

12 N. Hoffmann in Handbook of Photochemistry and Photobiology, $2^{\text {nd }}$ Ed. (Eds.: W. Horspool, F. Lenci), CRC Press, Boca Raton, 2004, pp. 34/1-34/20.

${ }^{13}$ N. Arai, T. Ohkuma, Heterocycles 2018, 96, 997.

${ }^{14}$ H. Haning, U. Niewöhner, T. Schenke, M. Es-Sayed, G. Schmidt, T. Lampe, E. Bischoff, Bioorg. Med. Chem. Lett. 2002, 12, 865.

${ }^{15}$ M. Brigotti, D. Carnicelli, P. Accorsi, S. Rizzi, L. Montanaro, S. Sperti, Nucleic Acid Res. 2000, $28,2383$.

${ }^{16}$ (a) A. Lablache-Combier in Handbook of Photochemistry and Photobiology (Eds.: W. Horspool, P.-S. Song), CRC Press, Boca Raton, 1995, 1063-1120. (b) J. W. Pavlik in Handbook of Photochemistry and Photobiology, $2^{\text {nd }}$ Ed. (Eds.: W. Horspool, F. Lenci), CRC Press, Boca Raton, 2004, pp. 97/1-97/22.

${ }^{17}$ R. F. Childs, Tetrahedron 1982, 38, 567.

18 P. Beak, W. Messer, Tetrahedron 1969, 25, 3287.

${ }^{19}$ H. Tiefenthaler, W. Dörscheln, H. Göth, H. Schmid, Helv. Chim. Acta 1967, 50, 2244.

${ }^{20}$ W. Heinzelmann, M. Märky, P. Gilgen, Helv. Chim. Acta 1976, 59, 1512. W. Heinzelmann, M. Märky, P. Gilgen, Helv. Chim. Acta 1976, 59, 1528.

${ }^{21}$ R. R. Sauers, L. M. Hadel, A. A. Scimone, T. A. Stevenson, J. Org. Chem. 1990, 55, 4011.

${ }^{22}$ K. H. Grellmann, E. Tauer, J. Photochem. 1977, 6, 365

${ }^{23}$ A. Lablache-Combier, A. Pollet, Tetrahedron 1972, 28, 3141. J. W. Pavlik, C. R. Pandit, C. J. Samuel, A. C. Day, J. Org. Chem. 1993, 58, 3407.

${ }^{24}$ For a computational study see: M.-D. Su, Phys. Chem. Chem. Phys. 2014, 16, 17030.

25 J. W. Pavlik, P. Tongacharoensirikul, N. P. Bird, A. C. Day, J. A. Barltrop, J. Am. Chem. Soc. 1994, $116,2292$.

${ }^{26}$ M. D'Auria, Tetrahedron 2002, 58, 8037.

27 J. W. Pavlik, H. St. Martin, K. A. Lambert, J. A. Lowell, V. M. Tsefrikas, C. K. Eddins, N. Kebede, J. Heterocyclic Chem. 2005, 42, 273.

${ }^{28}$ A. Pace, P. Pierro, Org. Biomol. Chem. 2009, 7, 4337.

${ }^{29}$ M.-D. Su, J. Org. Chem. 2009, 74, 6055.

${ }^{30}$ A. Pace, S. Buscemi, N. Vivona, A. Silvestri, G. Barone, J. Org. Chem. 2006, 71, 2740.

${ }^{31}$ S. Buscemi, M. C. Cicero, N. Vivona, T. Caronna, J. Heterocyclic Chem. 1988, 25, 931.

32 M. D’Auria, V. Frenna, S. Marullo, R. Racioppi, D. Spinelli, L. Viggiani, Photochem. Photobiol. Sci. $2012,11,1383$.

${ }^{33}$ Visible Light Photocatalysis in Organic Chemistry (Eds.: C. R. J. Stephenson, T. P. Yoon, D. W. C. MacMillan), WileyVCH, Weinheim, 2018.

34 M. Mei, D. Anand, L. Zhou, Org. Lett. 2019, 21, 3548.

${ }^{35}$ R. H. Prager, M. R. Taylor, C. M. Williams, J. Chem. Soc. Perkin Trans. 1, 1997, 2673.

${ }^{36}$ M. Nechab, S. Mondal, M. P. Bertrand, Chem. Eur. J. 2014, 20, 16034. 
${ }^{37}$ Y. Nakano, K. F. Biegasiewicz, T. K. Hyster, Curr. Opin. Chem. Biol. 2019, 49, 16.

${ }^{38}$ S. O. Scholz, E. P. Farney, S. Kim, D. M. Bates, T. P. Yoon, Angew. Chem. Int. Ed. 2016, 55, 2239.

${ }^{39}$ A. Padwa, F. Albrecht, P. Singh, E. Vega, J. Am. Chem. Soc. 1971, 93, 2928.

${ }^{40}$ N. Hoffmann, Synthesis 2016, 48, 1782. N. Hoffmann, Eur. J. Org. Chem. 2017, 2017, 1982.

${ }^{41}$ H. Aoyama, J. Chem. Soc., Perkin Trans. 1, 1997, 12, 1851.

${ }^{42}$ A. Sadayuki (Sumitomo chemical co), JP 0253229, 2017.

${ }^{43}$ B. Gerard, G. Jones, J. A. Porco, J. Am. Chem. Soc. 2004, 126, 13620.

${ }^{44}$ (a) L. Gustavo, T. A. Duarte, J. C. Germino, C. de Ávila Braga, C. A. Barboza, T. D. Z. Atvars, F. da Silveira Santos, F. S. Rdembusch, Photochem. Photobiol. Sci. 2018, 17, 231. (b) M. Sisa, S. L. Bonnet, D. Ferreira, J. H. Van der Westhuizen, Molecules 2010, 15, 5196.

${ }^{45}$ W. Wang, A. Clay, R. Krishnan, N. J. Lajkiewicz, L. E. Brown, J. Sivaguru, J. A. Porco, Angew. Chem. Int. Ed. 2017, $56,14479$.

${ }^{46}$ B. Xia, B. Gerard, D. M. Solano, J. Wan, G. Jones, J. A. Porco, Org. Lett. 2011, 13, 1346.

${ }^{47}$ P. A. Wender, D. B. Rawlins, Tetrahedron, 1992, 48, 7033.

${ }^{48}$ W. Oppolzer, K. Keller, Angew. Chem. Int. Ed. 1972, 11, 728.

${ }^{49} \mathrm{G}$. A. Kraus, L. Chen, Synlett, 1991, 2, 89.

${ }^{50}$ D. S. Reddy, A. G. Kutateladze, Org. Lett. 2019, 21, 2855.

${ }^{51}$ W. C. Cronk, O. A. Mukhina, A. G. Kutateladze, J. Org. Chem. 2014, 79, 1235.

${ }^{52}$ W. C. Cronk, O. A. Mukhina, A. G. Kutateladze, Org. Lett. 2016, 18, 3750.

${ }^{53}$ (a) T. Kumpulainen, B. Lang, A. Rosspeinter, E. Vauthey, Chem. Rev. 2017, 117, 10826. (b) V. Posey, K. Hanson, ChemPhotoChem 2019, 3, 580.

${ }^{54}$ E. G. Brown, Ring Nitrogen and Key Biomolecules : the biochemistry of $N$-heterocycles, Springer Netherlands, Dordrecht, 1998.

${ }^{55}$ N. A. McGrath, M. Brichacek, J. T. Njardarson, J. Chem. Educ. 2010, 87, 1348.

${ }^{56}$ P. J. Koovits, J. P. Knowles, K. I. Booker-Milburn, Org. Lett. 2016, 18, 5608.

${ }^{57}$ W. Li, Z. Chen, D. Yu, X. Peng, G. Wen, S. Wang, F. Xue, X.-Y. Liu, Y. Qin, Angew. Chem. Int. Ed. 2019, 58, 6059.

${ }^{58}$ C. Xie, J. Luo, Y. Zhang, S.-H. Huang, L. Zhu, R. Hong, Org. Lett. 2018, 20, 2386.

${ }^{59}$ C. Lefebvre, C. Michelin, T. Martzel, V. Djou'ou Mvondo, V. Bulach, M. Abe, N. Hoffmann, J. Org. Chem. 2018, 83, 1867.

${ }^{60}$ R. Jahjah, A. Gassama, V. Bulach, C. Suzuki, M. Abe, N. Hoffmann, A. Martinez, J.-M. Nuzillard, Chem. Eur. J. 2010, $16,3341$.

${ }^{61}$ I. Tomoharu, S. Yoshiyuki, N. Teruyuki, B. Makoto, N. Junichi, N. Toshio (Banyu Pharma Co LTD), JP 0052973, 2002.

62 G. M. Cragg, D. J. Newman, Biochim. Biophys. Acta, 2013, 1830, 3670.

${ }^{63} \mathrm{~T}$. Aniszewski, Alkaloids - Chemistry, Biology, Ecology, and Applications, $2^{\text {nd }}$ Ed., Elsevier B.V., Amsterdam, 2015.

${ }^{64}$ J.-C. Gramain, R. Remuson, D. Vallée, J. Org. Chem. 1985, 50, 710.

${ }^{65} \mathrm{~J}$. Wu, W. Zhang, C. Whang, Synthesis, 2009, 11, 1821.

${ }^{66}$ F. Cottet, L. Cottier, G. Descotes, Can. J. Chem. 1990, 68, 1251.

${ }^{67}$ W. He, Z. Zhang, D. Ma, Angew. Chem. Int. Ed. 2019, 58, 3972.

${ }^{68}$ C. Thommen, C. K. Jana, M. Neuburger, K. Gademann, Org. Lett. 2013, 15, 1390.

${ }^{69}$ G. A. Kraus, L. Chen, J. Am. Chem. Soc. 1990, 112, 3464.

${ }^{70}$ G. A. Kraus, N. Zhang, J. Org. Chem. 2000, 65, 5644.

${ }^{71}$ G. A. Kraus, P. J. Thomas, M. D. Schwinden, Tet. Lett. 1990, 31, 1819.

72 U. C. Yoon, P. S. Mariano, Acc. Chem. Res. 2001, 34, 523.

${ }^{73}$ M. Oelgemöller, A. G. Griesbeck, J. Photochem. Photobiol. C, 2002, 3, 109.

${ }^{74}$ M. Horvat, H. Görner, K.-D. Warzecha, J. Neudörfl, A. G. Griesbeck, K. Mlinarič-Majerski, N. Basarič, J. Org. Chem. 2009, 74, 8219.

${ }^{75}$ S. Hu, D. C. Neckers, Tetrahedron, 1997, 53, 7165.

${ }^{76}$ Y. Yamazaki, T. Miyagawa, T. Hesegawa, J. Chem. Soc., Perkin Trans. 1, 1997, 20, 2979.

77 U. Pischel, S. Abad, L. R. Domingo, F. Boscá, M. A. Miranda, Angew. Chem. Int. Ed. 2003, 115, 2635.

${ }^{78}$ S. Abad, F. Boscá, L. R. Domingo, S. Gil, U. Pischel, M. A. Miranda, J. Am. Chem. Soc. 2007, 129, 7407.

${ }^{79}$ A. Lewandowska-Andralojc, F. Kazmierczak, G. L. Hug, G. Hörner, B. Marciniak, Photochem. Photobiol. 2013, 89, 14.

${ }^{80}$ E. C. Taylor, W. W. Paudler, Tetrahedron Lett. 1960, 25, 1. 
${ }^{81}$ E. J. Corey, J. Streith, J. Amer. Chem. Soc. 1964, 86, 950.

82 R. C. De Selms and W. R. Schleigh, Tetrahedron Lett. 1972, 13, 3563.

${ }^{83}$ H. Furrer, Chem. Ber. 1972, 105, 2780.

${ }^{84}$ M. Sato, N. Katagiri, M. Muto, T. Haneda, C. Keneko, Tetrahedron Lett. 1986, $27,6091$.

85 J. Kurita, T. Yoneda, N. Kakusawa, T. Tsuchiya, Chem. Pharm. Bull. 1990, 38, 2911.

${ }^{86}$ L. Kaplan, J. W. Pavlik, K. E. Wilzbach, J. Am Chem. Soc. 1972, 94, 3283.

${ }^{87}$ C. Colombo, B. M. Pinto, A. Bernardi, A. J. Bennet, Org. Biomol. Chem. 2016, 14, 6539.

${ }^{88}$ F. Siopa, J. P. M. António, C. A. M. Afonso, Org. Process Res. Dev. 2018, 22, 551.

89 P. S. Mariano, X. Feng, E. N. Duesler, J. Org. Chem. 2005, 70, 5618.

${ }^{90}$ T. Damiano, D. Morton, A. Nelson, Org. Biomol. Chem. 2007, 5, 2735.

${ }^{91}$ J. Zhou, M. Gong, P. S. Mariano, U. C. Yoon, Bull. Korean Chem. Soc. 2008, $29,89$.

92 (a) M. Hanaoka, C. Mukai, K. Nagami, K. Okajima, S. Yasuda, Chem. Pharm. Bull. 1985, 32, 2230. (b) M. Hanaoka, M. Iwasaki, C. Mukai, Tetrahedron Lett. 1985, 26, 917.

${ }_{93}$ (a) T. Tsuchiya, J. Kurita, H. Kojima, Chem. Commun. 1980, 444. (b) J. Kurita, H. Kojima, T. Tsuchiya, Chem. Pharm. Bull. 1981, 29, 3688. 